\title{
Estimation of sea-ice thickness and volume in the Sea of Okhotsk based on ICESat data
}

\author{
Sohey NIHASHI, ${ }^{1}$ Nathan T. KURTZ, ${ }^{2}$ Thorsten MARKUS, ${ }^{2}$ Kay I. OHSHIMA, ${ }^{3}$ \\ Kazutaka TATEYAMA, ${ }^{4}$ Takenobu TOYOTA ${ }^{3}$ \\ ${ }^{1}$ Department of Engineering for Innovation, National Institute of Technology, Tomakomai College, 443 Nishikioka, \\ Tomakomai 059-1275, Japan \\ E-mail: sohey@tomakomai-ct.ac.jp \\ ${ }^{2}$ Cryospheric Sciences Laboratory, NASA Goddard Space Flight Center, Greenbelt, Maryland 20771, USA \\ ${ }^{3}$ Institute of Low Temperature Science, Hokkaido University, Kita-19, Nishi-8, Kita-ku, Sapporo 060-0819, Japan \\ ${ }^{4}$ Department of Civil Environmental Engineering, Kitami Institute of Technology, 165 Koen-cho, Kitami 090-8507, Japan
}

\begin{abstract}
Sea-ice thickness in the Sea of Okhotsk is estimated for 2004-2008 from ICESat derived freeboard under the assumption of hydrostatic balance. Total ice thickness including snow depth $\left(h_{t o t}\right)$ averaged over 2004-2008 is $95 \mathrm{~cm}$. The interannual variability of $h_{\text {tot }}$ is large; from $77.5 \mathrm{~cm}(2008)$ to 110.4 $\mathrm{cm}$ (2005). The mode of $h_{\text {tot }}$ varies from $50-60 \mathrm{~cm}(2007$ and 2008) to $70-80 \mathrm{~cm}(2005)$. Ice thickness derived from ICESat data is validated from a comparison with that observed by Electromagnetic Induction Instrument (EM) aboard the icebreaker Soya near Hokkaido, Japan. Annual maps of $\boldsymbol{h}_{\text {tot }}$ reveal that the spatial distribution of $h_{\text {tot }}$ is similar every year. Ice volume of $6.3 \times 10^{11} \mathrm{~m}^{3}$ is estimated from the ICESat derived $h_{\text {tot }}$ and AMSR-E derived ice concentration. A comparison with ice area demonstrates that the ice volume cannot always be represented by the area solely, despite the fact that the area has been used as a proxy of the volume in the Sea of Okhotsk. The ice volume roughly corresponds to that of annual ice production in the major coastal polynyas estimated based on heat budget calculations. This also supports the validity of the estimation of sea-ice thickness and volume using ICESat data.
\end{abstract}

KEYWORDS: remote sensing, sea ice, sea-ice geophysics

\section{INTRODUCTION}

The Sea of Okhotsk (Fig. 1) is the southernmost sea with a sizable seasonal sea-ice cover in the Northern Hemisphere. Satellite observations (e.g. Gloersen and others, 1992) show that the initial freezing occurs in the northern part of the sea. The ice cover maximum extent $\left(\sim 1.0 \times 10^{6} \mathrm{~km}^{2}\right.$ on average) occurs from the end of February to the beginning of March. The southernmost extent of sea ice reaches the coast of Hokkaido $\sim 44^{\circ} \mathrm{N}$. Interannual variability of the maximum ice area is large; $\sim 50-90 \%$ of the sea can be covered with ice and the ice typically melts away by June.

Freezing, transport and melting of sea ice cause a redistribution of heat, salt/fresh water and nutrients. In the Sea of Okhotsk, this process has been suggested to play an important role in the meridional ocean circulation and accordingly the climate and biogeochemical systems of the Sea of Okhotsk and the North Pacific regions. A coastal polynya formed in the northwest shelf region (Fig. 1) is the largest ice production area in the Northern Hemisphere (Ohshima and others, 2016). Additionally, a large amount of brine rejection associated with the active freezing forms cold and saline dense water (Shcherbina and others, 2003). This dense water is thought to be the main source for ventilation of the North Pacific Intermediate Water (NPIW; Talley and others, 1991; Warner and others, 1996). In this way, the sea-ice production in coastal polynyas in the Sea of Okhotsk drives the overturning in the North Pacific down to intermediate depths ( 200-800 m deep). This overturning can contribute to the material cycle and the subsequent biological productivity through the supply of nutrients such as iron (Nishioka and others, 2007). Recently, weakening of the overturning due to global warming and associated decrease in ice production has been suggested (Nakanowatari and others, 2007; Ohshima and others, 2014), thus monitoring of changes in sea-ice area and volume are needed to better understand changes in the region. Sea ice formed in the coastal polynyas is advected to the south by the prevailing winds and the East Sakhalin Current (Kimura and Wakatsuchi, 2000; Simizu and others, 2014). This leads to a transport of negative heat and fresh water from the north to the south by ice (Ohshima and others, 2003; Nihashi and others, 2012). Furthermore, sea ice also transports nutrients that affect the primary production in the south (Kanna and others, 2014).

Sea-ice volume is an important parameter for understanding the redistribution processes of heat, salt/fresh water, and nutrients by sea ice (Kwok and Rothrock, 1999; Nihashi and others, 2012; Haumann and others, 2016). Knowledge of the ice volume is also crucial to evaluate the impact of global warming on sea ice. The ice volume is determined by the area and thickness. The ice area has been monitored by passive microwave satellite observations for $>30$ years, and a decrease trend of $-11.9 \pm 3.3 \%$ decade $^{-1}$ was shown in the Sea of Okhotsk (Cavalieri and Parkinson, 2012). On the other hand, the ice thickness over a broad area has been hard to monitor from both in situ and satellite observations. Thus, until now the ice volume and its trend have been unknown in the Sea of Okhotsk.

At the southernmost area along the Hokkaido coast, measurements of ice draft (ice thickness below the sea surface) had been made by moored ice-profiling sonar (IPS) observations (Fukamachi and others, 2003, 2006). The ice 


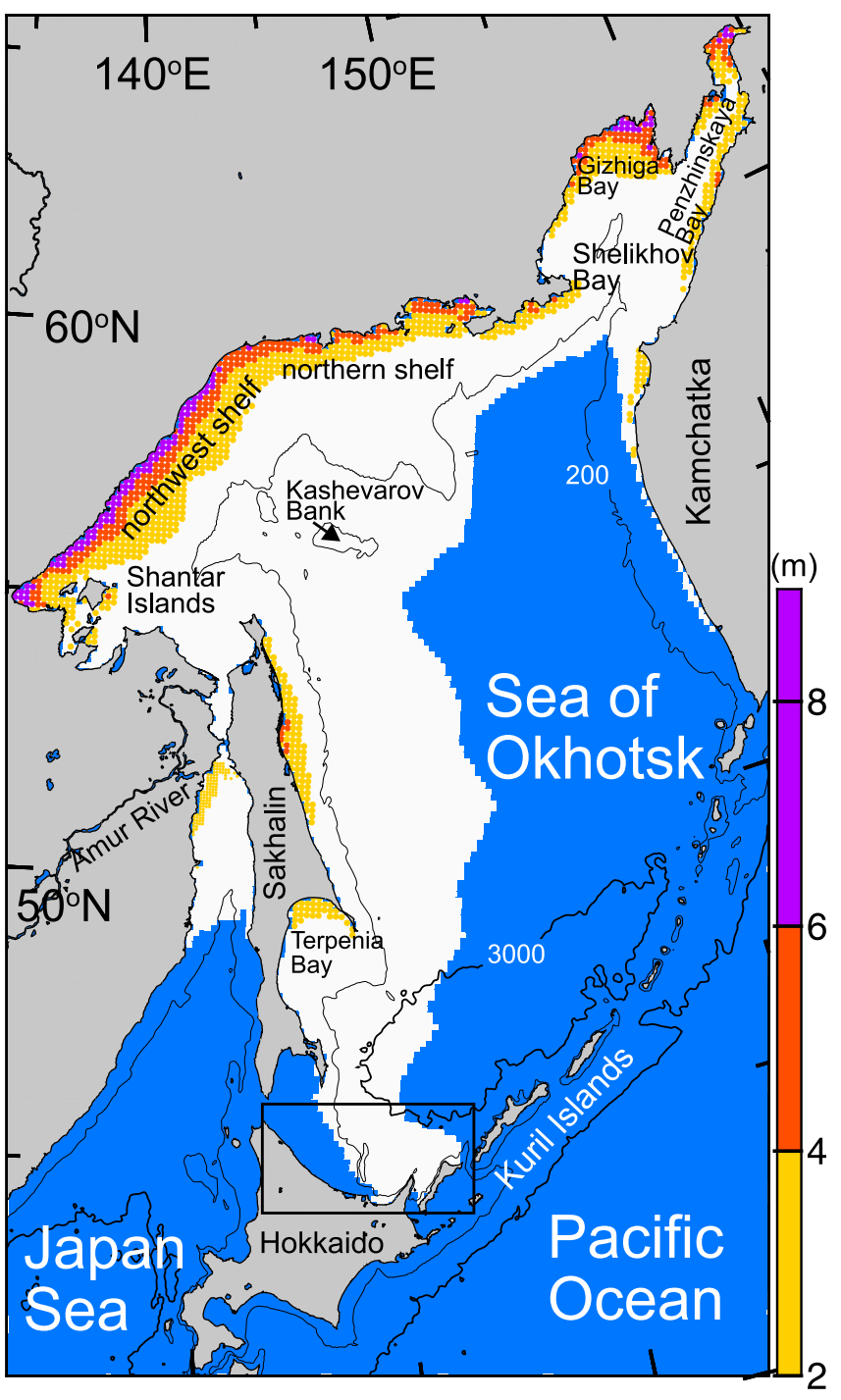

Fig. 1. Map of the Sea of Okhotsk with bottom topography. The 200and $3000-\mathrm{m}$ isobars are indicated by thin and thick solid lines, respectively. A box denotes the enlarged portion in Figure 5. White shading indicates sea-ice area (ice concentration $\geqslant 30 \%$ ) in February averaged for 2003-11; blue shading indicates open ocean area. Ice concentration from AMSR-E is used. Color shadings indicate cumulative ice production in coastal polynyas during winter (December-March) averaged from the 2002/03 to 2009/10 seasons (modified from Nihashi and others, 2012, 2017). The amount is indicated by the bar scale.

draft averaged over 1999-2000 is $0.6 \mathrm{~m}$; the annual mean draft ranges between 0.49 and $0.72 \mathrm{~m}$ (Fukamachi and others, 2006). Similar IPS observations had been conducted near Sakhalin; the ice draft averaged over 2002/03 is 1.05 $\mathrm{m}$ (Fukamachi and others, 2009). Since a coastal polynya is formed at this site, the ice draft can be separated into distinct periods of thin and thick ice. The ice draft averaged over these thin and thick periods are $0.17 \mathrm{~m}$ and $1.95 \mathrm{~m}$, respectively. The thin ice corresponds to the coastal polynya period, while the thick ice is due to drifting of heavily deformed pack ice formed in the north. Near Hokkaido, in situ sea-ice monitoring has been conducted every February by the icebreaker Soya, a patrol vessel of the Japan Coast Guard. Ice thickness was measured from the ship by video and visual observations. The video observations revealed that thickness of undeformed (level) ice averaged over 1991-2000 is $0.33 \mathrm{~m}$
(Toyota and others, 2004). Interannual variability of the thickness is large; annual mean thickness of level ice for the above period ranges between 0.19 and $0.55 \mathrm{~m}$. From a comparison with the ice draft measured using moored IPS near Hokkaido (Fukamachi and others, 2003), the ice thickness measured by video observation is validated (Toyota and others, 2004). The visual observation revealed that ice thickness averaged over 2003-05 is $111 \mathrm{~cm}$ (Toyota and others, 2007), with the primary difference from the video observations being due to the fact that the visual observations included deformed (ridged) ice. Ice-thickness measurements by Electromagnetic Induction Instrument (EM) aboard the icebreaker Soya have been conducted since 2004 (Tateyama and others, 2006), and the ice thickness was validated from comparisons with that measured by the drill-hole observations within the accuracy of $\sim 10 \%$ of the thickness (Uto and others, 2006; Toyota and others, 2009).

Ice thickness estimation based on satellite observation has been also attempted in the Sea of Okhotsk. Ice thickness was estimated from a radar backscatter image near Hokkaido acquired by synthetic aperture radar (SAR) based on comparisons with ice thickness observed aboard the icebreaker Soya (Nakamura and others, 2006). Toyota and others (2011) showed ice thickness distributions of the southern Sea of Okhotsk during 2007-09 based on an empirical relationship between the SAR backscatter and ice thickness (surface roughness). The annual mean ice thickness was shown to range between 0.33 and $0.42 \mathrm{~m}$. From a numerical model, ice thickness distributions over the entire Sea of Okhotsk have been simulated (Watanabe and others, 2004). The model results showed that the ice is thick $(\sim 3.5 \mathrm{~m})$ at the southern end of the Shantar Islands.

The Geoscience Laser Altimeter System (GLAS) instrument on the Ice, Cloud and land Elevation Satellite (ICESat) was launched in January 2003, and operated until October 2009. One of two channels of GLAS (at $1064 \mathrm{~nm}$ ) is used for surface altimetry measurement (Zwally and others, 2002). The footprint size of the laser is $\sim 70 \mathrm{~m}$ and the measurement interval is $\sim 170 \mathrm{~m}$ along the track. Retrieval of sea-ice freeboard (height of the ice plus snow surface above sea level) has been achieved from the surface elevation measurements by ICESat (Kwok and others, 2004, 2006, 2007; Forsberg and Skourup, 2005; Markus and others, 2011).

In the Arctic Ocean, which is predominantly covered by relatively thick multi-year ice, basin-scale ice thickness distribution was estimated based on ICESat-derived freeboard (Kwok and others, 2009). They also showed that ice drafts from ICESat and moored IPSs are consistent within $0.5 \mathrm{~m}$ in the Chukchi and Beaufort seas. Ice thickness estimation using ICESat data in the Arctic Ocean has also been conducted by Kurtz and others (2009). Zwally and others (2008) and Kern and Spreen (2015) had estimated sea-ice thickness from ICESat-derived freeboard in the Weddell Sea, Southern Ocean, where relatively thick ice exists. Kurtz and Markus (2012) estimated sea-ice thickness from ICESat-derived freeboard over the entire Southern Ocean, which is a typical seasonal ice zone similar to the Sea of Okhotsk (the ice thickness was found to be thinner than that in the Arctic Ocean). The objective of this study is to show the retrieval of the sea-ice thickness distribution and volume over the entire Sea of Okhotsk based on ICESat data. 


\section{METHODS AND DATA}

A schematic illustration for the ice thickness estimation is shown in Figure 2. Total thickness of the sea ice above and below the water level $\left(h_{i}\right)$ can be calculated from ICESatderived freeboard $\left(h_{f}\right)$ and snow depth $\left(h_{s}\right)$ under the assumption of hydrostatic balance, as follows:

$$
h_{i}=\frac{\rho_{s}-\rho_{w}}{\rho_{w}-\rho_{i}} h_{s}+\frac{\rho_{w}}{\rho_{w}-\rho_{i}} h_{f}
$$

From ice core observations (Toyota and others, 2007), snow and ice densities are assumed to be $\rho_{s}=225 \mathrm{~kg} \mathrm{~m}^{-3}$ and and $\rho_{i}=888 \mathrm{~kg} \mathrm{~m}^{-3}$, respectively. Sea-water density is assumed to be $\rho_{w}=1026 \mathrm{~kg} \mathrm{~m}^{-3}$ from CTD observations (Ohshima and others, 2001). Based on a relationship between ice thickness and snow depth obtained from in situ measurements (Toyota and others, 2007), $h_{s}$ is given by,

$$
h_{s}=0.1 h_{i}
$$

The estimation of $h_{i}$ highly depends on the $\rho_{s} \rho_{i}$ and $h_{s}$ values. Errors in the $h_{i}$ estimation caused by uncertainty of these parameters are discussed in the summary and discussions section.

In this study, $h_{f}$ is estimated from surface elevation measured by ICESat ( $h_{\text {obs }}$; Zwally and others, 2003), following a method by Kurtz and Markus (2012). Filtering of the data are first done since the $h_{o b s}$ value is significantly affected by atmospheric scattering due to cloud and blowing snow. The biased $h_{o b s}$ data are removed using instrument and waveform-derived parameters that are provided along with the $h_{o b s}$ data. To obtain $h_{f}$, the local sea surface height $\left(h_{s s h}\right)$ is subtracted from $h_{\text {obs }}$. The local sea surface height determined by geoid, tides and atmospheric pressure

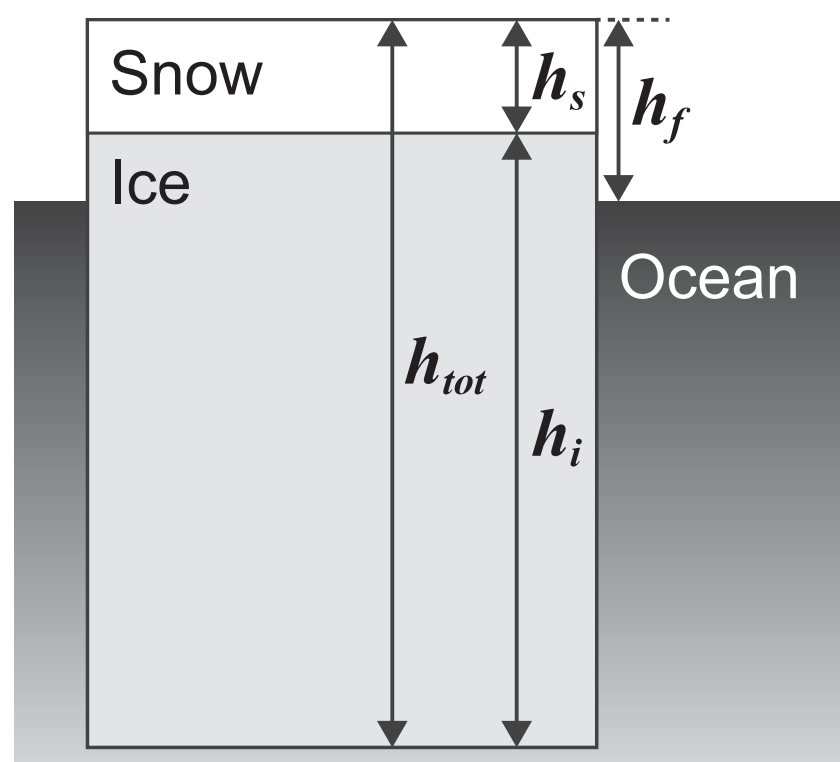

Fig. 2. Schematics of sea-ice for estimation of total thickness of ice above and below the water level $\left(h_{i}\right)$ from ICESat-derived freeboard $\left(h_{f}\right)$. Here, $h_{s}$ is snow depth and $h_{\text {tot }}\left(=h_{s}+h_{i}\right)$ is total ice thickness including snow depth. variations $\left(h_{\text {est }}\right)$ is first estimated, and subtracted from the $h_{o b s}$ data. By using the $h_{o b s}$ and $h_{\text {est }}$ values, $h_{f}$ is given by

$$
h_{f}=h_{o b s}-h_{e s t}-h_{t p},
$$

where $h_{t p}$ is the sea surface tie point. The $h_{t p}$ value is taken to be the average of the lowest three values of $h_{o b s}-h_{\text {est }}$ that are within $\pm 12.5 \mathrm{~km}$ along-track spatial distance from each measurement.

\section{RESULTS}

ICESat-derived $h_{f}$ in the Sea of Okhotsk is shown in Figure 3 and the annual and monthly mean $h_{f}$ are shown in Table 1. The data obtained from late-February to mid-March were used, except in 2007 when the data obtained from midMarch to mid-April were used. These periods are determined by the original ICESat collection periods (Zwally and others, 2003). In this study, all available spring ICESat data in the Sea of Okhotsk were used. The number of data points used indicates that the annual mean value is mainly determined by the data in March (Table 1). Sea-ice concentration derived from the Advanced Microwave Scanning Radiometer for EOS (AMSR-E) on the Aqua satellite averaged for February-March (March-April in 2007) is also shown in Figure 3. These periods correspond to the timing of the maximum ice extent. Daily mean ice concentration by Cavalieri and others (2004) were used. The ice concentration data are mapped onto a NSIDC polar stereographic grid at a spatial resolution of $\sim 12.5 \mathrm{~km}$. Sea-ice area (ice area excluding open water fraction) is also shown in Table 1 . In this study, the ice edge is defined as the $30 \%$ ice concentration contour following Nihashi and others (2012). Interannual variability of the ice area is large; the largest area occurred in 2004 while the area in 2006 and 2007 was relatively small (Fig. 3). The climatology of $h_{f}$ averaged over the entire period of $2004-08$ is $18.3 \mathrm{~cm}$ (Table 1).

Total sea-ice thickness with snow depth $\left(h_{t o t}=h_{i}+h_{s}\right)$ which is calculated from Eqns (1) and (2) using $h_{f}$ is also shown in Figure 3. The correspondence between $h_{f}$ and $h_{\text {tot }}$ is indicated by the color bars. The annual mean $h_{t o t}$ is thinnest in 2008 when the thickness was $77.5 \mathrm{~cm}$ (Table 1). The thickest ice was in 2005 when the ice thickness reached $110.4 \mathrm{~cm}$. These reveal that interannual variability of ice thickness is large. No clear relationship between the sea-ice thickness and area is shown (Table 1). The climatological value of $h_{\text {tot }}$ averaged over the entire period of 2004-2008 is $95.0 \mathrm{~cm}$. The frequency histogram of $h_{\text {tot }}$ is shown in Figure 4. The peak of the histogram (mode) varies between the 50-60 cm thickness bin (2007 and 2008) to the 70-80 cm bin (2005; Table 1).

To investigate the quality of the ice thickness retrievals from ICESat data, we compare with thickness observations by EM aboard the icebreaker Soya near Hokkaido. Unfortunately, the ICESat data near Hokkaido is available only for 3 years of 2004, 2005 and 2008 (Fig. 3). The total ice thickness $\left(h_{\text {tot }}\right)$ from EM measurements is shown in Figure 5a, c, and e with the periods indicated in Table 2. The EM measurements have been carried out in almost the same area and period every year. Close-up maps of the ICESat-derived $h_{\text {tot }}$ corresponding to the periods of the EM measurements are shown in Figure $5 b, d$ and $f$. The periods of the ICESat measurements are also indicated in Table 2. 

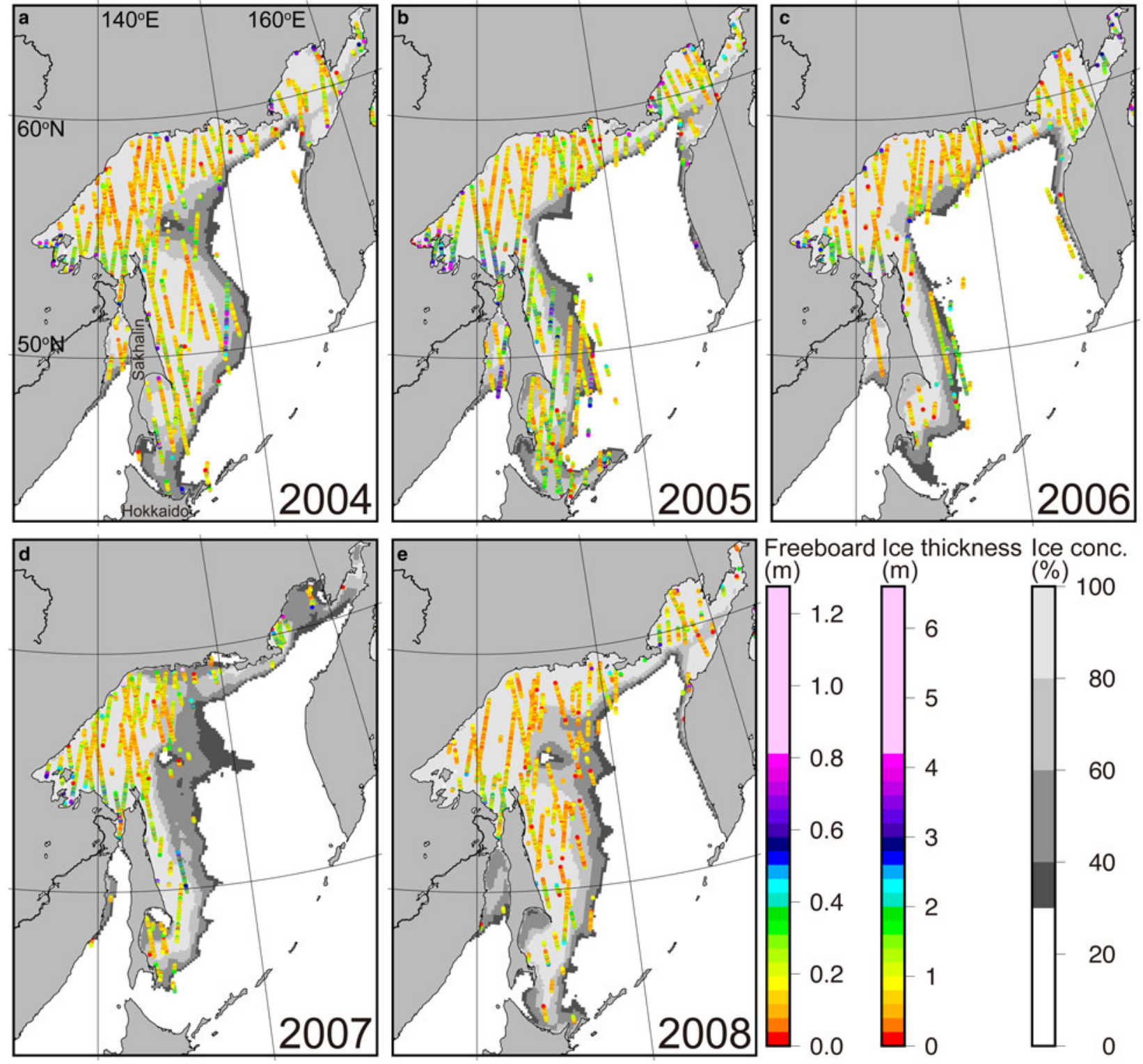

Fig. 3. ICESat-derived freeboard $\left(h_{f}\right)$ and total ice thickness ( $h_{\text {tot }}$; color) superimposed on AMSR-E derived ice concentration (gray shadings) averaged for February-March (March-April in 2007), when the ICESat data was acquired. In 2004, 2007 and 2008, the Kashevarov Bank polynya, which is a sensible heat polynya (Polyakov and Martin, 2000), formed at the Kashevarov Bank region (Fig. 1).

The ICESat measurements in 2004 and 2008 were carried out 10 days after the EM measurements while the temporal gap is 3 days in 2005. In 2004, maps of daily ice concentration (not shown) indicate that the ice edge had advanced between the EM and ICESat observations. Since the temporal gap of the measurements is short in 2005, significant differences with the sea-ice area were not seen. In 2008, the ice edge had retreated between the EM and ICESat observations.

The EM and ICESat-derived $h_{\text {tot }}$ are compared by averaging them within an analysis area indicated by a box in Figure 5, this was done because the temporal gap between EM and ICESat data are not small and their footprint size is largely different $(10 \mathrm{~m}$ vs $70 \mathrm{~m})$. The areas close to Hokkaido, where the effects of convergent ice motion and land contamination are expected to be relatively large, are excluded from the analysis area. The averaged $h_{\text {tot }}$ with spatial Std dev. are shown in Figure 6. The interannual variability of the averaged $h_{\text {tot }}$ derived from EM and ICESat data roughly corresponds with each other. In 2004, the averaged $h_{\text {tot }}$ derived from EM and ICESat data are $87.5 \pm 53.4 \mathrm{~cm}$ and
$84.2 \pm 35.7 \mathrm{~cm}$, respectively. The mode of $h_{\text {tot }}$ derived from the EM and ICESat data are $60-70 \mathrm{~cm}$ bin and $70-80 \mathrm{~cm}$ bin, respectively. In that year, the average and modal values are close. In 2005, the averaged $h_{\text {tot }}$ derived from EM data are $107.6 \pm 81.3 \mathrm{~cm}$, while that from ICESat data are $181.5 \pm 69.9 \mathrm{~cm}$. The mode of the ICESat-derived $h_{\text {tot }}$ is $160-170 \mathrm{~cm}$, and it is close to the average value. However, the mode of the EM derived $h_{\text {tot }}$ is $0-10 \mathrm{~cm}$ bin. This indicates that thin ice was dominant around the ship because the EM, whose footprint size is $\sim 10 \mathrm{~m}$, measures ice thickness at the side of the ship. On the other hand, visual observations, in which sea ice is observed in the viewing range of $\sim 1 \mathrm{~km}$, reveal that thicker ice which exceeds continuous ice breaking capability of the ship $(>1 \mathrm{~m})$ was prominent. The thin modal value of $h_{\text {tot }}$ derived from EM data $(0-10 \mathrm{~cm}$ bin) indicates that the ship tended to look for thin ice area where the ship can break ice easily and continuously. Even so, the averaged $h_{\text {tot }}$ in 2005 from EM data are thickest among the 3 years. In 2008, averaged $h_{\text {tot }}$ derived from EM and ICESat data are $45.4 \pm 39.6 \mathrm{~cm}$ and $70.6 \pm 29.8 \mathrm{~cm}$, 
Table 1. Summary of statistics of sea-ice parameters

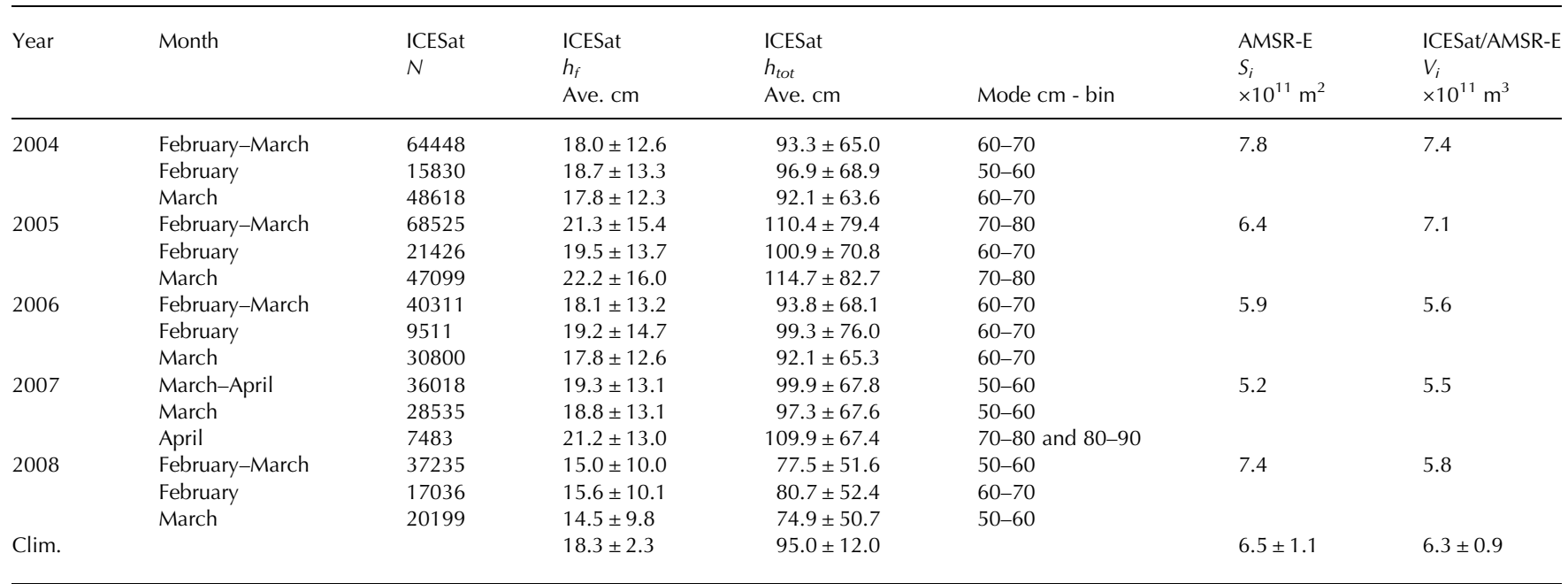

Here $N$ is number of ICESat data points. The terms $h_{f}$ and $h_{\text {tot }}$ indicate freeboard and total ice thickness derived from ICESat data, respectively. For $h_{f}$ and $h_{\text {tot }}$ those averaged over the entire sea-ice zone with spatial Std dev. are shown. For $h_{\text {tot, }}$ the modal values are also shown. The term $S_{i}$ indicates net sea-ice area which is given by excluding the open water fraction. For calculating $S_{i}$, ice concentration derived from AMSR-E data are used. The term $V_{i}$ indicates sea-ice volume obtained from the ICESat $h_{\text {tot }}$ and AMSR-E ice concentration. The term Clim. in the bottom row indicates climatology averaged for 5-years of 200408 with annual Std dev.

respectively. The modal values of $h_{\text {tot }}$ derived from EM and ICESat data are the $40-50 \mathrm{~cm}$ and $60-70 \mathrm{~cm}$ bins, respectively.

A strict comparison of $h_{\text {tot }}$ cannot be made from Figure 6, because data of only 3 years is available and the temporal gap between EM and ICESat data reaches nearly 10 days (Table 2). In the Sea of Okhotsk, sea ice formed in the northern coastal polynyas is advected to the south by the prevailing winds and the East Sakhalin Current, and finally reaches the coast of Hokkaido (Kimura and Wakatsuchi, 2000; Simizu and others, 2014). The comparison area of sea-ice thickness is surrounded by the coast of the Kuril Islands and Hokkaido (Figs 1 and 5). Therefore, the advected sea ice is expected to drift around the analysis area for a certain period, because the sea-ice floes must pass narrow straits of the Kuril Islands to flow out into the Pacific. If the averaged $h_{\text {tot }}$ derived from EM data represents that of the year, the relationship of $h_{\text {tot }}$ shown in Figure 6 validates the ICESat-derived $h_{\text {tot }}$.

The ICESat-derived $h_{\text {tot }}$ (Fig. 3 ) is interpolated onto a polar stereographic grid at a spatial resolution of $\sim 12.5 \mathrm{~km}$ using a Gaussian weighting function. This grid is same as that for the AMSR-E ice concentration data. To reveal the spatial distribution of sea-ice thickness over the entire Sea of Okhotsk for the first time, all data of each year, except for the Japan Sea, was used for the interpolation. In the Southern Ocean, a similar spatial interpolation of ICESat-derived ice thickness was made by Kurtz and Markus (2012), and the influence radius was set at $125 \mathrm{~km}$. In this study, the influence radius
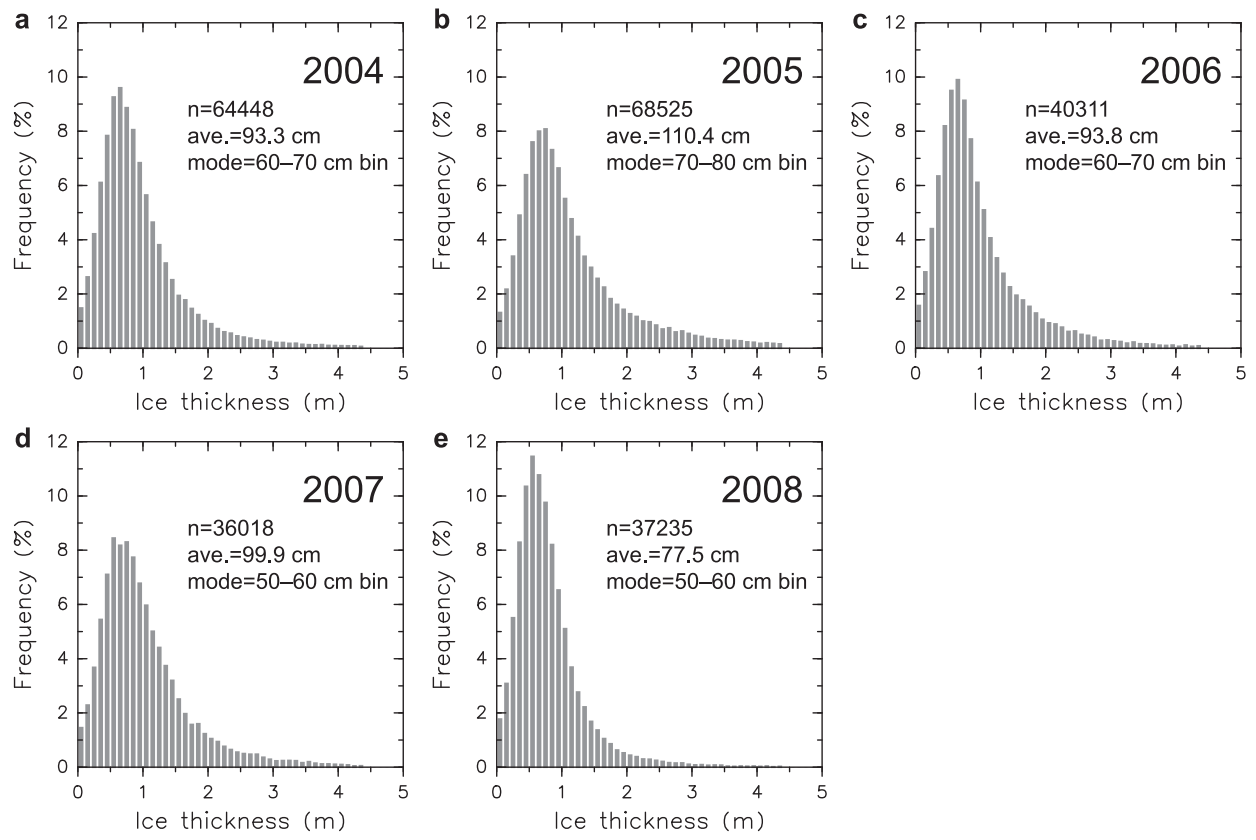

Fig. 4. Frequency histograms of total ice thickness $\left(h_{\text {tot }}\right)$ derived from ICESat. The histogram bin size is $10 \mathrm{~cm}$. $n$ indicates the total number of data points. 

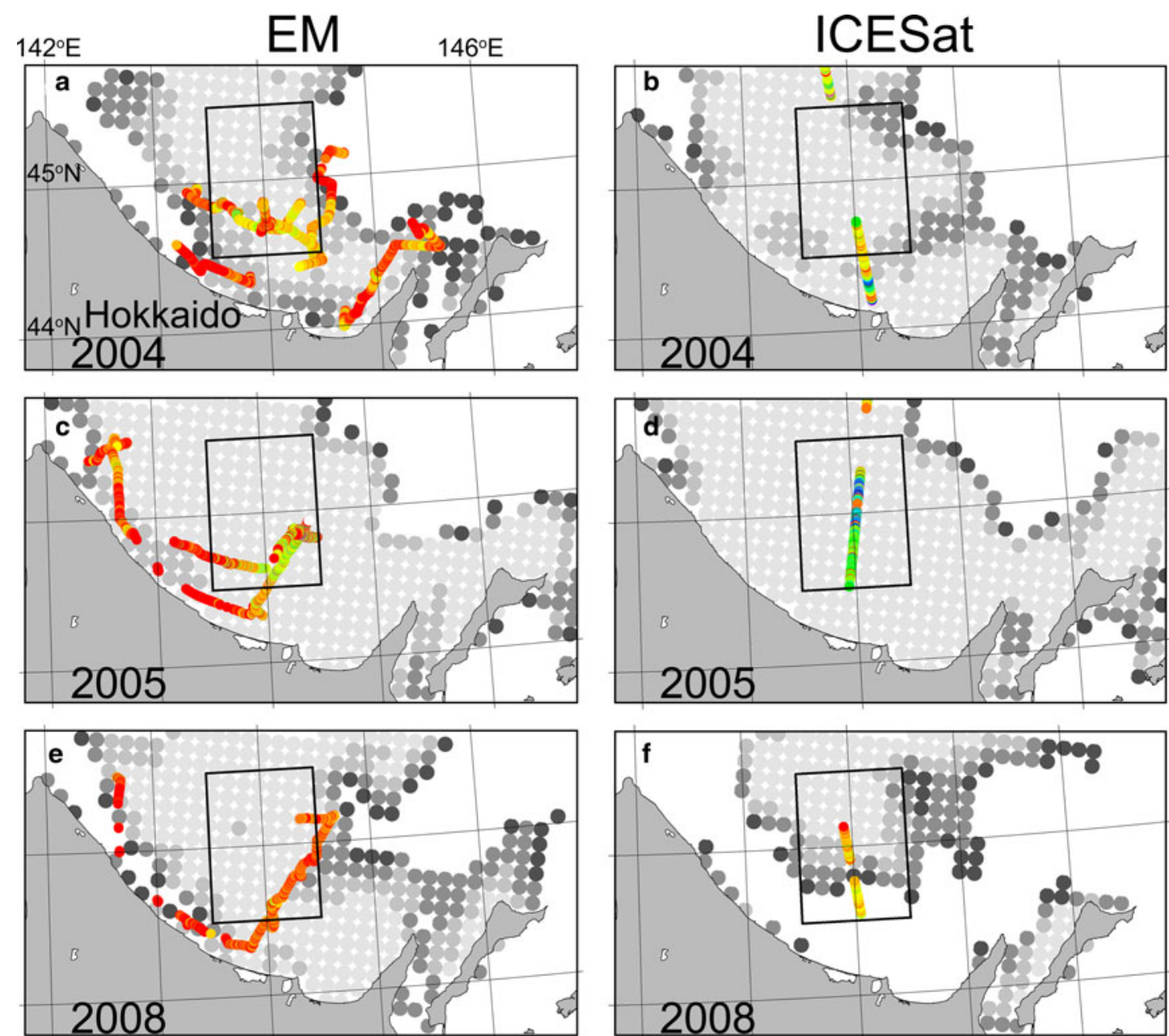

\section{Ice thickness $(m)$}
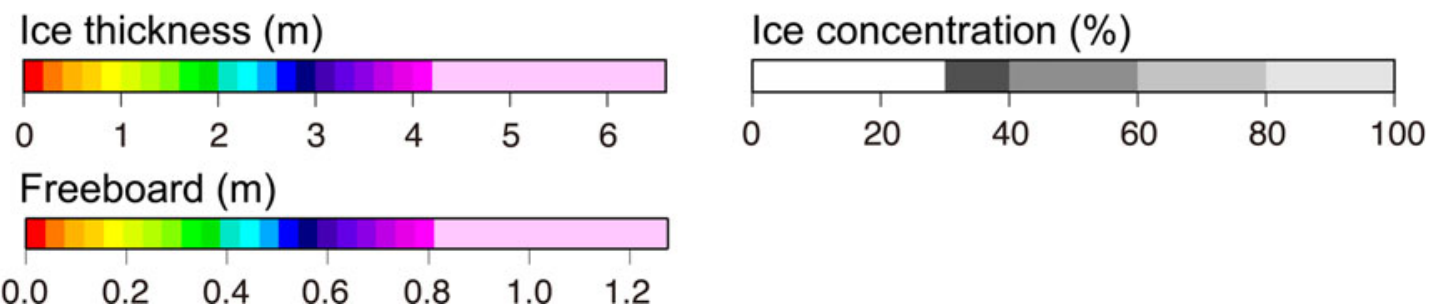

Fig. 5. (a, c and e) Total ice thickness $\left(h_{t o t}\right)$ derived from EM measurements onboard the icebreaker 'Soya'. (b, $d$ and f) Freeboard $h_{f}$ and $h_{t o t}$ derived from ICESat measurements. The observation periods are indicated in Table 2. Sea-ice concentration derived from AMSR-E of the corresponding period is indicated by gray shadings. A box denotes the analysis area for Figure 6.

was set at $210 \mathrm{~km}$ because the spatial distribution of ICESat data are relatively sparse in the Sea of Okhotsk which is located at lower latitude. The spatial distribution of $h_{\text {tot }}$ mapped onto the polar stereographic grid is shown in Figure 7. The open ocean is masked as the area where the AMSR-E ice concentration averaged from February to March (from March to April in 2007) is $<30 \%$. Ice thickness

Table 2. The periods of EM observations aboard the icebreaker 'Soya' near Hokkaido and date of ICESat measurements in the area

\begin{tabular}{lll}
\hline & EM & ICESat \\
\hline 2004 & 8-12 February & 20 February \\
2005 & $14-16$ February & 18 February \\
2008 & $10-11$ February & 20 February \\
\hline
\end{tabular}

is relatively thin at the northwest shelf and north shelf regions where coastal polynyas are formed (Nihashi and others, 2009). On the other hand, ice thickness is relatively thick south of the Shantar Islands. This is considered to be caused by convergent ice motion. Similarly, ice thickness is relatively thick near Hokkaido. Ice thickness is relatively thick also in the Shelikhov and Penzhinskaya Bays. This might be caused by sea-ice deformation due to strong tides in this area (Kowalik and Polyakov, 1998). The spatial distribution of sea-ice thickness is similar every year, although the thickness is different. For example, the thickness in 2008 is thinnest over almost the entire sea-ice zone. The spatial distribution of ice thickness derived from ICESat data are roughly similar to that from a numerical model (Watanabe and others, 2004).

In 2005, when the average $h_{\text {tot }}$ is the thickest (Table 1), the position of the Aleutian Low in January was somewhat 


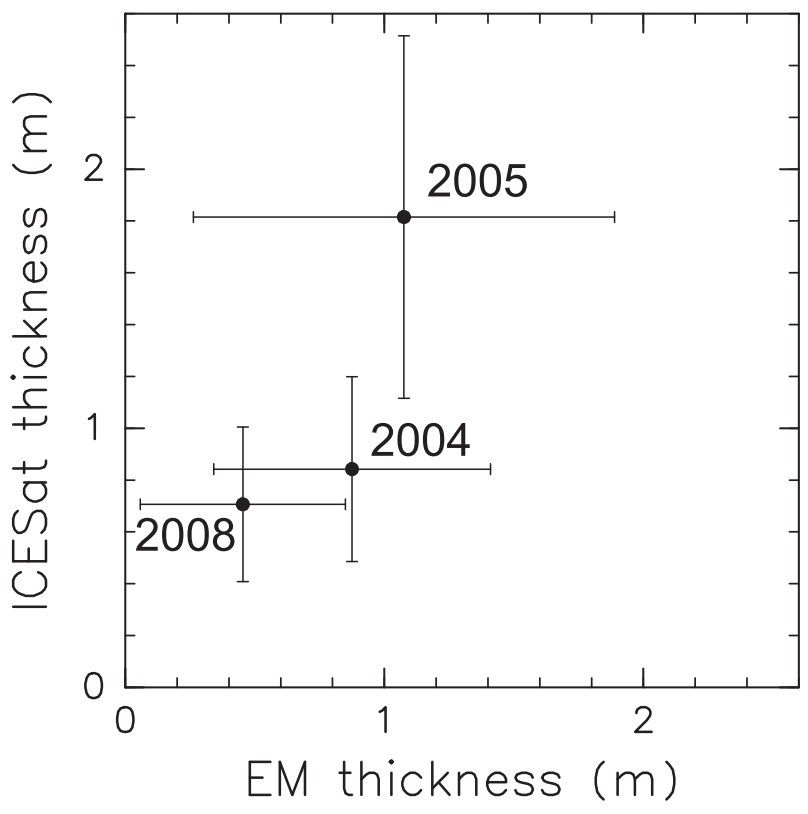

Fig. 6. A scatter plot of total ice thickness $\left(h_{\text {tot }}\right)$ derived from EM and ICESat data. The ice thickness was averaged over the analysis area shown in Figure 5. Error bars indicate the spatial standard deviations of $h_{\text {tot }}$.

to the south of its usual location (Fig. 8a and c). This indicates that the westward wind component which leads to convergent ice motion was relatively strong. The thickest ice in 2005 is considered to be caused by deformation of ice due to this anomalous wind. On the other hand, in 2008 when the average total thickness is the thinnest (Table 1), the position of the Aleutian Low in January was somewhat to the northeast of the normal location (Fig. 8b and $\mathrm{c}$ ). This indicates that the eastward wind component which leads to divergent ice motion was relatively strong. These results indicate that the synoptic scale wind is an important factor causing interannual variability of ice thickness in the Sea of Okhotsk.

Sea-ice volume is estimated from AMSE-E derived ice area (concentration) averaged for February-March (March-April in 2007) multiplied by the ICESat-derived $h_{\text {tot }}$ (Fig. 7) at each gridpoint. Total ice volume (sum of ice volume over the sea-ice gridpoints) in the Sea of Okhotsk is compared with annual ice production in major coastal polynyas (northwest shelf region, north shelf region, Gizhiga Bay, coastal regions of western Kamchatka and northeastern Sakhalin, and Terpenia Bay; Fig. 1). This ice production is based on heat budget calculation using thin ice thickness derived from AMSR-E (Nihashi and others, 2012). A time series of the ice volume is shown in Figure 9. For comparison, a time series of sea-ice area (Table 1) is superimposed on the figure. Variability of the ice volume roughly corresponds to that presumed from the ice area if the thickness is assumed to be $1 \mathrm{~m}$. However, ice volume in 2008 is relatively small owing to the lowest ice thickness (Table 1). This indicates that ice area cannot be used as a proxy of ice volume. Time series of annual ice production in the major coastal polynyas is also shown in Figure 9. The ice volume and annual ice production estimated from independent data are generally comparable. This also supports validity of the estimations of sea-ice thickness and volume from satellite altimetry data.

\section{SUMMARY AND DISCUSSIONS}

In the entire sea-ice zone of the Sea of Okhotsk, the total sea-ice thickness including snow depth $\left(h_{t o t}\right)$ for 2004-08 was estimated using ICESat-derived freeboard (Fig. 3), and revealed the spatial distribution of thickness for the first time (Fig. 7). The $h_{\text {tot }}$ derived from ICESat data roughly corresponded with that derived from EM data near Hokkaido (Fig. 6). The errors in the $h_{\text {tot, }}$ which is calculated from Eqns (1) and (2), are mainly caused by the densities of snow $\left(\rho_{s}\right)$ and sea-ice $\left(\rho_{i}\right)$, snow depth $\left(h_{s}\right)$, and ICESatderived freeboard $\left(h_{f}\right)$. In this study, densities of snow and sea ice were assumed to be $\rho_{s}=225 \mathrm{~kg} \mathrm{~m}^{-3}$ and $\rho_{i}=888$ $\mathrm{kg} \mathrm{m}^{-3}$, respectively. These values are based on in situ measurements, and variations of $\rho_{s}$ and $\rho_{i}$ were estimated as $\pm 109 \mathrm{~kg} \mathrm{~m}^{-3}$ and $\pm 23 \mathrm{~kg} \mathrm{~m}^{-3}$, respectively (Toyota and others, 2007). The $h_{\text {tot }}$ errors caused by $\rho_{s}$ and $\rho_{i}$ are estimated by using these values. In the winter Arctic Ocean, relatively higher values of $\rho_{s}\left(300-320 \mathrm{~kg} \mathrm{~m}^{-3}\right)$ are shown (Warren and others, 1999). It is noted that the $\rho_{s}$ value $\left(225 \pm 109 \mathrm{~kg} \mathrm{~m}^{-3}\right)$ used in the error estimation covers these relatively higher $\rho_{s}$ values in the Arctic Ocean. The ratio of $h_{\text {tot }}$ changed by the perturbation of $\rho_{s}$ and $\rho_{i}$ are $\sim \pm 5 \%$ and $\sim \pm 10 \%$, respectively. For example, in a case of $h_{\text {tot }}=95.0 \mathrm{~cm}$, which is estimated from a mean freeboard $h_{f}$ of $18.3 \mathrm{~cm}$ (Table 1 ), the errors caused by $\rho_{s}$ and $\rho_{i}$ are $\sim \pm 5 \mathrm{~cm}$ and $\sim \pm 10 \mathrm{~cm}$, respectively. In this study, snow depth $h_{s}$ was assumed to be $10 \%$ of the ice thickness $h_{i}$ (Eqn 2) based on in situ measurements (Toyota and others, 2007). From the in situ measurements of snow depth, a regression line of $h_{s}=0.041 h_{i}+6.070(\mathrm{~cm})$ was shown in Toyota and others (2007). However, we did not use this regression line, because a negative $h_{i}$ value is calculated when the $h_{f}$ value is small $\left(h_{f}<\sim 5 \mathrm{~cm}\right)$. It is noted that $h_{\text {tot }}$ estimated from a mean $h_{f}$ of $18.3 \mathrm{~cm}$ using this regression line for $h_{s}$ is $\sim 93 \mathrm{~cm}$, and this $h_{\text {tot }}$ value is similar to that estimated assuming that $h_{s}=0.1 h_{i}(95 \mathrm{~cm}$; Table 1$)$. When $h_{s}$ is assumed that $h_{s}=0.05 h_{i}$ based on the in situ measurements by Toyota and others (2007), $h_{\text {tot }}$ is estimated to be $\sim 45 \%$ thicker than the baseline case in which $h_{s}$ was assumed that $h_{s}=0.1 h_{i}$. On the other hand, $h_{\text {tot }}$ is estimated to be $\sim 15 \%$ thinner than the baseline case when $h_{s}$ is assumed that $h_{s}=0.15 h_{i}$. The uncertainty of $h_{f}$ has previously been shown to be $1.8 \mathrm{~cm}$ (Markus and others, 2011). This causes the $h_{\text {tot }}$ error of $\sim 9.3 \mathrm{~cm}$. These estimations indicate that the $h_{\text {tot }}$ errors owing to $\rho_{s}, \rho_{i}, h_{s}$ and $h_{f}$ do not affect the validation of the ice thickness estimation shown in Figure 6 .

Interannual variability of $h_{\text {tot }}$ averaged over the entire sea-ice zone was shown to be large. The minimum value is $77.5 \mathrm{~cm}$ in 2008, while the maximum value is $110.4 \mathrm{~cm}$ in 2005 (Table 1). A frequency histogram of $h_{\text {tot }}$ (Fig. 4) revealed that the mode varies from $50-60 \mathrm{~cm}$ thickness bin in 2007 and 2008 to $70-80 \mathrm{~cm}$ bin in 2005 (Table 1). These thickness values are much higher than the maximum thickness of thermodynamically grown pack ice without deformation observed in the Antarctic Ocean (0.3-0.4 m; e.g. Allison and Worby, 1994; Jeffries and others, 1997; Wadhams and others, 1987). This indicates that deformed ice is prominent over the entire Okhotsk sea-ice zone as suggested from in situ observations of sea ice in the southernmost part of the sea (Toyota and others, 2004 , 2007). Furthermore, the large tails of the distributions (Fig. 4) and mean thickness values of $>\sim 80 \mathrm{~cm}$ (Table 1) 

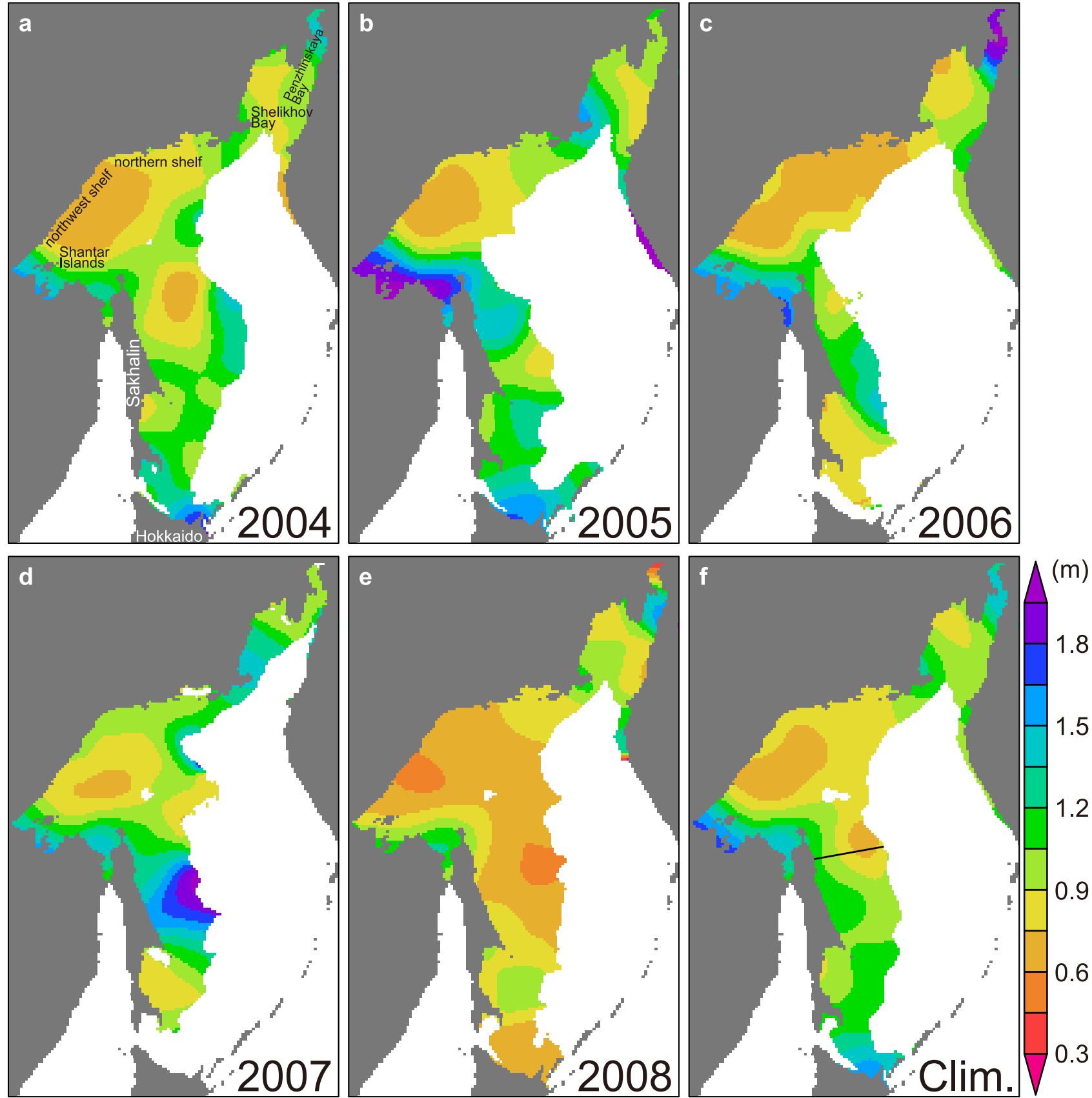

Fig. 7. ICESat-derived total ice thickness $h_{\text {tot }}$ interpolated onto the polar stereographic grid at the $12.5 \mathrm{~km}$ spatial resolution. (f) Climatology of $h_{\text {tot }}$ averaged for 2004-08. A black line denotes an analysis area along $53^{\circ} \mathrm{N}$ used in Summary and Discussions. The sea-ice data in the Japan Sea is masked out.

indicate that the deformed ice affects ice volume in the Sea of Okhotsk.

Ice volume in the Sea of Okhotsk was estimated from ICESat-derived $h_{\text {tot }}$ and AMSR-E derived ice concentration (Fig. 9). Sea-ice area has been used for a proxy of ice volume in the Sea of Okhotsk when there is no ice thickness information (e.g., Nihashi and others, 2011). However, the results of this study indicated that ice area cannot always represent the ice volume (Fig. 9), as in the case of 2008 when the average ice thickness was thin (Table 1). The ice volume estimated in this study was shown to roughly correspond to ice production in major coastal polynyas estimated based on heat flux calculations (Fig. 9). This supports the validity of ice thickness and volume estimation based on ICESat data.
In the Sea of Okhotsk, sea ice formed in the northern coastal polynyas is advected to the south by the prevailing northerly winds and the southward East Sakhalin Current. This indicates a transportation of negative heat, fresh water and nutrients to the south by sea ice. Simizu and others (2014) estimated the southward ice-volume transport using sea-ice drift based on the moored Acoustic Doppler Current Profiler (ADCP), an ocean model simulation, objective analysis data of the wind, and satellite sea-ice data. Since there was no ice thickness information, they simply assumed a uniform ice thickness of $1 \mathrm{~m}$. The cumulative southward ice transport per winter, which crosses a line along $53^{\circ} \mathrm{N}$ (Fig. 1), was estimated to be $3.0 \times 10^{11} \mathrm{~m}^{3}$. From the climatology of ICESat-derived $h_{\text {tot }}$ of this study (Fig. $7 f$ ), $h_{\text {tot }}$ averaged on the line is estimated to be $\sim 85 \mathrm{~cm}$. Furthermore, $h_{\text {tot }}$ 

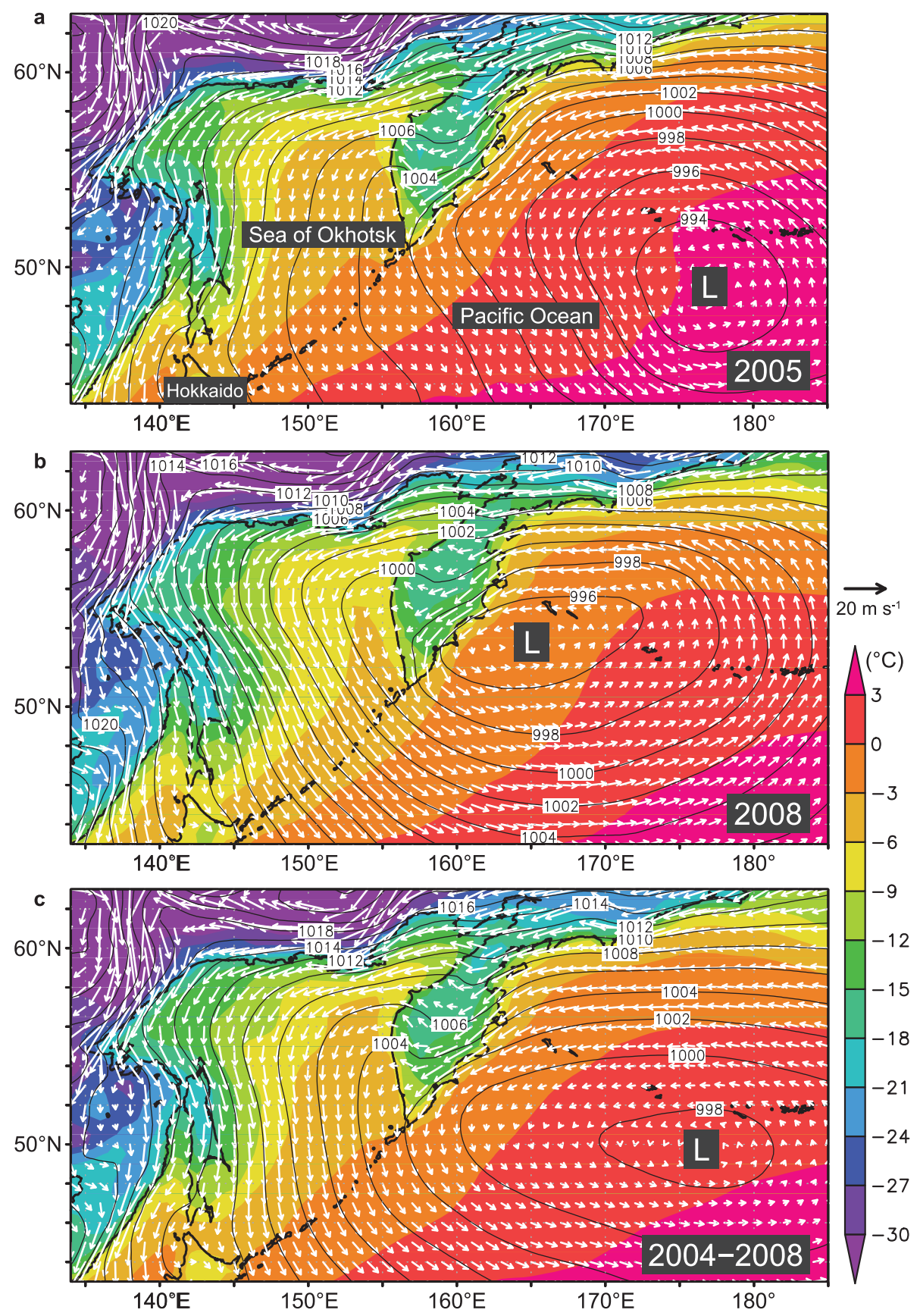

Fig. 8. (a) Sea-level pressure (solid lines), geostrophic wind (vectors), and air temperature at $2 \mathrm{~m}$ (colors), averaged for the sea-ice advance season (January) in 2005. (b) As in (a), but for data in 2008. (c) As in (a), but for data averaged for 2004-08. We used near-surface atmospheric data from the 6-hourly ECMWF interim reanalysis (ERA-Interim) dataset with a spatial resolution of $0.5^{\circ} \times 0.5^{\circ}$.

averaged over the entire Sea of Okhotsk is $95 \mathrm{~cm}$ (Table 1). These indicate that the assumption of ice thickness of $1 \mathrm{~m}$ in Simizu and others (2014) was almost appropriate. When the ICESat-derived $h_{\text {tot }}(=85 \mathrm{~cm})$ is adopted to the estimation by Simizu and others (2014), the cumulative southward ice transport per winter is estimated to be $2.6 \times 10^{11} \mathrm{~m}^{3}$. This ice transport is comparable with the climatological annual discharge of the Amur River (Fig. 1) of $3.1 \times 10^{11} \mathrm{~m}^{3}$ (Fig. 1; Dai and others, 2009).

The primary goal of this study was to reveal the spatial distribution of sea-ice thickness in the Sea of Okhotsk for the first time. In order to understand changes in sea ice associated with climate change, a decadal time series of sea-ice volume is needed. Sea-ice area in the Sea of Okhotsk has been decreasing at a rate of $\sim 12 \%$ decade $^{-1}$ for the last 30 years (Cavalieri and Parkinson, 2012). Furthermore, sea-ice production also has been decreasing $\sim 11 \%$ for the last 30 years due to warming in autumn at the land area northwest of the Sea of Okhotsk (Kashiwase and others, 2014). Creating a decadal-scale record of ice thickness requires merging multiple satellite records. ICESat covers only for the period of 2004-08. In April 2010, a radar altimeter on CryoSat-2 was launched, and ice thickness and volume can be estimated also from this data (e.g. Laxon and others, 2013). By combining the CryoSat-2 data (2010-) with the ICESat data, a time series of ice volume that covers $>10$ years can be obtained. However, the CryoSat-2 data cannot be directly compared with the ICESat data because the observation periods do not overlap. Furthermore, as shown in Table 2 and Figures 5 and 6, a strict comparison of ice thickness between satellite and in situ observations also cannot be made in the Sea of Okhotsk owing to the 


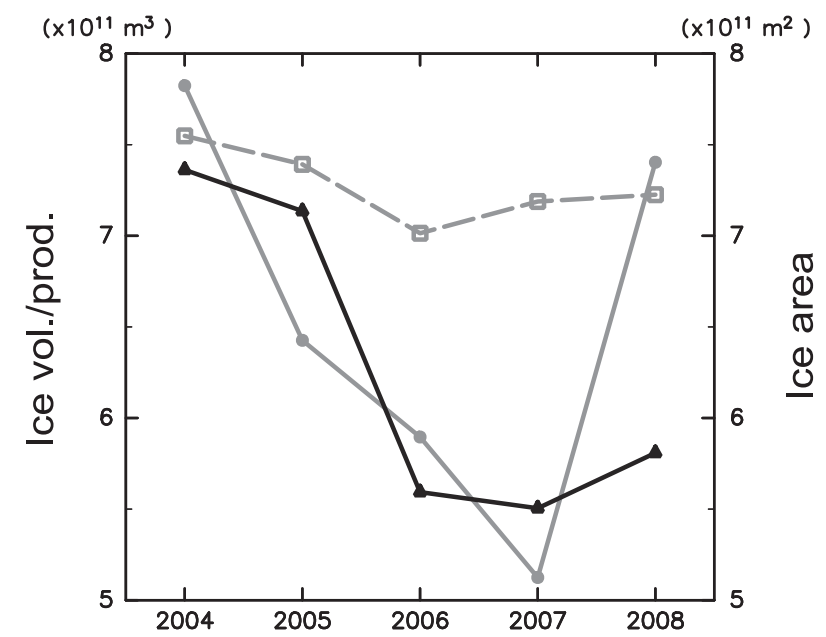

Fig. 9. Time series of ice volume (black solid line with triangles), ice area (gray solid line with dots) and ice production in major coastal polynyas (gray dashed line with squares) in the Sea of Okhotsk.

large temporal gap of the measurements. Therefore, we have not included the CryoSat-2 data in this study, because reliability of the time series of ice volume requires a further indepth study. In 2018, ICESat-2, which is a successor to ICESat used in this study, is planned for launch. This data can be compared with the CryoSat-2 data. In the future, analysis combining these satellite-derived ice thickness would be important for discussing the longer term variability of ice volume in the Sea of Okhotsk where the strong influence of global warming on sea ice has been implicated.

\section{ACKNOWLEDGEMENTS}

The ICESat data were obtained from the NASA National Snow and Ice Data Center (NSIDC) Distributed Active Archive Center. The AMSR-E data were provided by the NSIDC. Comments from the editor and two reviewers were very helpful. This work was supported by Grant-in-Aids for Scientific Research (17K00530) of the Japanese Ministry of Education, Culture, Sports, Science and Technology (MEXT).

\section{REFERENCES}

Allison I and Worby AP (1994) Seasonal changes of sea-ice characteristics off East Antarctica. Ann. Glaciol., 20, 195-201

Cavalieri DJ and Parkinson CL (2012) Arctic sea ice variability and trends, 1979-2010. Cryosphere 6(4), 881-889 (doi: 10.5194/ tc-6-881-2012)

Cavalieri DJ, Markus T and Comiso JC (2004) AMSR-E/Aqua daily L3 $12.5 \mathrm{~km}$ Sea Ice concentration. Boulder. NASA National Snow and Ice Data Center Distributed Active Archive Center, Colorado, USA (doi: 10.5067/AMSR-E/AE SI12.003)

Dai A, Qian T, Trenberth KE and Milliman JD (2009) Changes in continental freshwater discharge from 1948 to 2004. J. Clim., 22, 2773-2792

Forsberg R and Skourup H (2005) Arctic Ocean gravity, geoid and sea-ice freeboard heights from ICESat and GRACE. Geophys. Res. Lett., 32, L21502 (doi: 10.1029/2005GL023711)

Fukamachi $Y$ and 5 others (2003) Variability of sea-ice draft off Hokkaido in the Sea of Okhotsk revealed by a moored ice-profiling sonar in winter of 1999. Geophys. Res. Lett., 30(7), 1376 (doi: 10.1029/2002GL016197)

Fukamachi $Y$ and 5 others (2006) Sea ice thickness in the southwestern Sea of Okhotsk revealed by a moored ice-profiling sonar. J. Geophys. Res., 111, C09018 (doi: 10.1029/ 2005JC003327)

Fukamachi $Y$ and 8 others (2009) Direct observations of sea-ice thickness and brine rejection off sakhalin in the Sea of Okhotsk. Cont. Shelf Res., 29, 1541-1548

Gloersen P and 5 others (1992) Arctic and Antarctic sea ice, 19781987: satellite passive microwave observations and analysis. NASA SP-511, Scientific and Technical Information Program, NASA, Washington, DC

Haumann FA, Gruber N, Münnich M, Frenger I and Kern S (2016) Sea-ice transport driving Southern Ocean salinity and its recent trends. Nature, 537, 89-92 (doi: 10.1038/nature19101)

Jeffries MO, Worby AP, Morris K and Weeks WF (1997) Seasonal variations in the properties and structural composition of sea ice and snow cover in the Bellingshausen and Amundsen Seas, Antarctic. J. Glaciol., 43(143), 138-151

Kanna N, Toyota T and Nishioka J (2014) Iron and nutrient concentration in the sea ice and its impact on surface nutritional status in the southern Okhotsk Sea. Prog. Ocean., 126, 44-57

Kashiwase H, Ohshima KI and Nihashi S (2014) Long-term variation in sea ice production and its relation to intermediate water in the Sea of Okhotsk. Prog. Ocean., 126, 21-32 (doi: 10.1016/j. pocean.2014.05.004)

Kern S and Spreen G (2015) Uncertainties in Antarctic sea-ice thickness retrieval from ICESat. Ann. Glaciol., 56(69), 107-119

Kimura N and Wakatsuchi M (2000) Relationship between sea-ice motion and geostrophic wind in the Northern Hemisphere. Geophys. Res. Lett., 27(22), 3735-3738

Kowalik Z and Polyakov I (1998) Tides in the Sea of Okhotsk. J. Phys. Oceanogr., 28, 1389-1409

Kurtz NT and Markus T (2012) Satellite observations of Antarctic sea ice thickness and volume. J. Geophys. Res., 117, C08025 (doi: 10.1029/2012JC008141)

Kurtz NT and 6 others (2009) Estimation of sea ice thickness distributions through the combination of snow depth and satellite laser altimetry data. J. Geophys. Res., 114, C10007 (doi: 10.1029/ 2009JC005292)

Kwok R and Rothrock DA (1999) Variability of Fram Strait ice flux and North Atlantic Oscillation. J. Geophys. Res., 104, 51775189 (doi: 10.1029/1998JC900103)

Kwok R, Zwally HJ and Yi D (2004) ICESat observations of Arctic sea ice: a first look. Geophys. Res. Lett., 31, L16401 (doi: 10.1029/ 2004GL020309)

Kwok R, Cunningham GF, Zwally HJ and Yi D (2006) ICESat over Arctic sea ice: interpretation of altimetric and reflectivity profiles. J. Geophys. Res., 111, C06006 (doi: 10.1029/ 2005JC003175)

Kwok R, Cunningham GF, Zwally HJ and Yi D (2007) Ice, cloud, and land elevation satellite (ICESat) over Arctic sea ice: retrieval of freeboard. J. Geophys. Res., 112, C12013 (doi:10.1029/ 2006JC003978)

Kwok R and 5 others (2009) Thinning and volume loss of the Arctic ocean sea ice cover: 2003-2008. J. Geophys. Res., 114, C07005 (doi: 10.1029/2009JC005312)

Laxon SW and 14 others (2013) CryoSat-2 estimates of Arctic sea ice thickness and volume. Geophys. Res. Lett., 40, 732-737 (doi: 10.1002/grl.50193)

Markus T and 5 others (2011) Freeboard, snow depth and sea-ice roughness in East Antarctica from in situ and multiple satellite data. Ann. Glaciol., 52(57), 242-248

Nakamura $\mathrm{K}$ and 5 others (2006) Sea-ice thickness retrieval in the Sea of Okhotsk using dual-polarization SAR data. Ann. Glaciol., 44(1), 261-268

Nakanowatari T, Ohshima KI and Wakatsuchi M (2007) Warming and oxygen decrease of intermediate water in the northwestern North Pacific, originating from the Sea of Okhotsk, 1995-2004. Geophys. Res. Lett., 34, L04602 (doi: 10.1029/ 2006GL028243)

Nihashi S, Ohshima KI, Tamura T, Fukamachi Y and Saitoh S (2009) Thickness and production of sea ice in the Okhotsk Sea coastal 
polynyas from AMSR-E. J. Geophys. Res., 114, C10025 (doi: 10.1029/2008JC005222)

Nihashi S, Ohshima KI and Nakasato H (2011) Sea-ice retreat in the Sea of Okhotsk and the ice-ocean albedo feedback effect on it. J. Oceanogr., 67, 551-562 (doi: 10.1007/s10872-0110056-x)

Nihashi S, Ohshima KI and Kimura N (2012) Creation of a heat and salt flux dataset associated with sea-ice production and melting in the Sea of Okhotsk. J. Clim., 25, 2261-2278 (doi: 10.1175/ JCLI-D-11-00022.1)

Nihashi S, Ohshima KI and Saitoh SI (2017) Sea-ice production in the northern Japan Sea. Deep Sea Res. I, 127, 65-76 (doi: 10.1016/j.dsr.2017.08.003)

Nishioka J and 12 others (2007) Iron supply to the western subarctic Pacific: importance of iron export from the Sea of Okhotsk. J. Geophys. Res., 112, C10012 (doi: 10.1029/2006JC004055)

Ohshima KI and 7 others (2001) Winter oceanographic conditions in the southwestern part of the Okhotsk Sea and their relation to sea ice. J. Oceanogr., 57, 451-460

Ohshima KI, Watanabe T and Nihashi S (2003) Surface heat budget of the Sea of Okhotsk during 1987- 2001 and the role of sea ice on it. J. Meteorol. Soc. Jpn., 81, 653-677

Ohshima KI, Nakanowatari T, Riser S, Volkov Y and Wakatsuchi M (2014) Freshening and dense shelf water reduction in the Okhotsk Sea linked with sea ice decline. Prog. Oceanogr., 126, 71-79

Ohshima KI, Nihashi S and Iwamoto K (2016) Global view of sea-ice production in polynyas and its linkage to dense/bottom water formation. Geosci. Lett., 3(13) (doi: 10.1186/s40562-016-0045-4)

Polyakov I and Martin S (2000) Interaction of the Okhotsk Sea diurnal tides with the Kashevarov bank polynya, J. Geophys. Res., 105, 3281-3294 (doi: 10.1029/1999JC900308)

Shcherbina AY, Talley LD and Rudnick DL (2003) Direct observations of North Pacific ventilation: brine rejection in the Okhotsk Sea. Science, 302, 1952-1955

Simizu D, Ohshima KI, Ono J, Fukamachi Y and Mizuta G (2014) What drives the southward drift of sea ice in the Sea of Okhotsk? Prog. Oceanogr. 126, 33-43

Talley LD (1991) An Okhotsk water anomaly: implications for ventilation in the North Pacific. Deep Sea Res., 38(Suppl. 1), S171-S190

Toyota T, Kawamura T, Ohshima KI, Shimoda $\mathrm{H}$ and Wakatsuchi $\mathrm{M}$ (2004) Thickness distribution, texture and stratigraphy, and a simple probabilistic model for dynamical thickening of sea ice in the southern Sea of Okhotsk. J. Geophys. Res., 109, C6 (doi: 10.1029/2003JC002090)

Toyota T, Takatsuji S, Tateyama K, Naoki K and Ohshima KI (2007) Properties of sea ice and overlying snow in the southern Sea of Okhotsk. J. Oceanogr., 63, 393-411

Toyota T, K Nakamura, S Uto, KI Ohshima and N and Ebuchi (2009) Retrieval of sea ice thickness distribution in the seasonal ice zone from air-borne L-band SAR. Int. J. Remote Sens., 30(12), 3171-3189

Toyota T, Ono S, Cho K and Ohshima KI (2011) Retrieval of sea-ice thickness distribution in the Sea of Okhotsk from ALOS/PALSAR backscatter data. Ann. Glaciol., 52(57), 177-184

Tateyama K and 5 others (2006) Standardization of electromagneticinduction measurements of sea-ice thickness in polar and subpolar seas. Ann. Glaciol., 44(1), 240-246

Uto S, Toyota T, Shimoda H, Tateyama K and Shirasawa K (2006) Ship-borne electromagnetic induction sounding of sea-ice thickness in the southern Sea of Okhotsk. Ann. Glaciol., 44(1), 253-260

Wadhams P, Lange MA and Ackley SF (1987) The ice thickness distribution across the Atlantic sector of the Antarctic Ocean in midwinter. J. Geophys. Res., 92(C13), 14,535-15,552

Warner MJ, Bullister JL, Wisegarver DP and Gammon RH (1996) Basin-wide distributions of chlorofluorocarbons CFC-11 and CFC-12 in the North Pacific: 1985-1989. J. Geophys. Res., 101, 20,525-20,542

Warren SG and 6 others (1999), Snow depth on Arctic sea ice. J. Clim., 12, 1814-1829

Watanabe T, Ikeda M and Wakatsuchi M (2004) Thermohaline effects of the seasonal sea ice cover in the Sea of Okhotsk. J. Geophys. Res., 109, C09S02 (doi: 10.1029/2003JC001905)

Zwally HJ and 15 others (2002) ICESat's laser measurements of polar ice, atmosphere, ocean, and land. J. Geodyn., 34, 405-445 (doi: 10.1016/S0264-3707(02)00042-X)

Zwally HJ and 7 others (2003) GLAS/ICESat L2 Sea Ice Altimetry Data V531, Oct. 2003 to March 2008, http://nsidc.org/data/ gla13.html, Natl. Snow and Ice Data Cent., Boulder, Colo

Zwally HJ, Yi D, Kwok R and Zhao Y (2008) ICESat measurements of sea ice freeboard and estimates of sea ice thickness in the Weddell Sea. J. Geophys. Res., 113, C02S15 (doi: 10.1029/ 2007JC004284) 